\title{
Microphytoplankton structure from the neritic and oceanic regions of Pernambuco State - Brazil
}

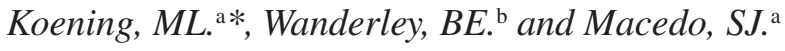 \\ aDepartamento de Oceanografia, Campus Universitário, \\ Universidade Federal de Pernambuco - UFPE, \\ Av. Arquitetura, s/n, Cidade Universitária, CEP 50601-910, Recife, PE, Brazil

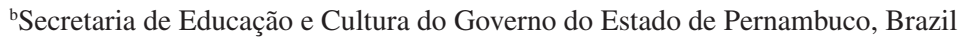 \\ *e-mail: koening@ufpe.br
}

Received May 2, 2008 - Accepted November 20, 2008 - Distributed November 30, 2009

(With 6 figures)

\begin{abstract}
This research was carried out to assess phytoplankton diversity, distribution and ecology on the Pernambuco Continental Shelf and Oceanic region (lat. 7 $33^{\prime} 00^{\prime}$ ' S to $8^{\circ} 41^{\prime} 50^{\prime \prime} \mathrm{S}$ and long. $34^{\circ} 04^{\prime} 47^{\prime \prime} \mathrm{W}$ to $35^{\circ} 01^{\prime} 20^{\prime \prime} \mathrm{W}$ ). Samples were collected during the Joint Oceanographics Projects (JOPS II-Leg 5) by double oblique hauls with a baby bongo net $64 \mu \mathrm{m}$ mesh size at depth between 14 and $150 \mathrm{~m}$ in inshore and offshore waters respectively, in seven transects, totaling 34 stations. The temperature and salinity characterised the tropical water masses. The dissolved oxygen was oversaturated in all stations. The nutrient-low concentrations showed an oligothrophic pattern in the whole area. 173 specific and infraspecific taxa were identified: Dinophyta (103 taxa), Bacillariophyta (61 taxa), Cyanobacteria (7 taxa), Chlorophyta and Chrysophyta (1 taxon). The family Ceratiaceae presented the highest species number (47 taxa). The cyanobacteria Trichodesmium erythraeum Ehrenberg, Oscillatoria spp. and the diatom Leptocylindrus danicus Cleve had higher frequence of occurrence and abundance. Species diversity varied from 0.71 to 3.46 bits.cell $^{-1}$ and this low index was due to Trichodesmium erythraeum bloom and evenness from 0.14 to 0.65 , showing an unstable pattern. The oceanic planktonic species were responsible for the higher richness with 78 taxa, corresponding to $58.39 \%$ of the total microphytoplankton. The species association presented two groups. The first one divided in two subgroups: one associated to the neritic/oceanic and oceanic planktonic species and the other to the oligotrophic indicator species. The second group was composed of some key species which were the most abundant and frequent in the area. The first three Principal Component Analyses (PCAs) explained 50.91\% of the data variance showing that the area is structured by two groups: one offshore composed by oligotrophic indicators, and another nearshore influenced by continental fluxes.
\end{abstract}

Keywords: microphytoplankton, diversity, neritic and oceanic regions, Brazil.

\section{Estrutura do microfitoplâncton de áreas neríticas e oceânicas do Estado de Pernambuco - Brasil}

\begin{abstract}
Resumo
O presente trabalho foi desenvolvido com o objetivo de ampliar os conhecimentos sobre a diversidade, distribuição e ecologia da comunidade fitoplanctônica na Plataforma Continental de Pernambuco e área oceânica (lat. $7^{\circ} 33^{\prime} 00^{\prime \prime} \mathrm{S}$ a $8^{\circ} 41^{\prime} 50^{\prime \prime} \mathrm{S}$ e long. $34^{\circ} 04^{\prime} 47^{\prime \prime} \mathrm{O}$ a $35^{\circ} 01^{\prime} 20^{\prime} \mathrm{O}$ ). As coletas foram realizadas durante a prospecção Joint Oceanographics Project (JOPS II- Leg 5), através de arrastos oblíquos utilizando-se uma rede do tipo baby bongo com abertura de malha de $64 \mu \mathrm{m}$ a profundidades entre $14 \mathrm{~m}$ para as estações neríticas e $150 \mathrm{~m}$ para as estações oceânicas, em sete perfis perpendiculares à costa, totalizando 34 estações. A temperatura e a salinidade apresentaram características de Água Tropical. O oxigênio dissolvido manteve-se elevado durante todo em todas as estações. As baixas concentrações de nutrientes apresentaram um padrão oligotrófico em toda a área. Foram identificados 173 táxons específicos e infraespecíficos: Dinophyta (103 táxons); Bacillariophyta (61 táxons); Cyanobactéria (7 táxons); Chlorophyta e Chrysophyta (1 táxon). A família Ceratiaceae apresentou maior riqueza, com 47 táxons. As cianobactérias Trichodesmium erythraeum Ehrenberg, Oscillatoria spp. e a diatomácea Leptocylindrus danicus Cleve caracterizaram a área em termos de frequência de ocorrência e dominância, respectivamente. A diversidade específica variou de 0,71 a 3,46 bits.cél $^{-1}$, sendo estes baixos índices caracterizados pelo predomínio de Trichodesmium erythraeum. A equitabilidade variou de 0,14 a 0,65. As espécies marinhas planctônicas oceânicas se destacaram com 78 dos táxons representando 58,39\% do microfitoplâncton total. A associação das espécies permitiu evidenciar dois grupos. O pri-
\end{abstract}


meiro, subdivido em dois subgrupos: o primeiro associado às espécies planctônicas neríticas/oceânicas e oceânicas e o segundo, às espécies indicadoras de condições oligotróficas. O segundo grupo associou algumas espécies chave que caracterizaram a área em termos de dominância e frequência de ocorrência. $\mathrm{Na}$ análise dos componentes principais (ACP), os três primeiros fatores foram responsáveis por 50,91\% da variância dos dados, mostrando que a área está estruturada por dois grupos: um composto por espécies indicadoras de oligotrofia e o outro, por espécies costeiras influenciadas por fluxo continental.

Palavras-chave: microfitoplâncton, diversidade, região nerítica e oceânica, Brasil.

\section{Introduction}

This study is part of the Joint Oceanographic Projects (JOPS-II), a bilateral cooperation agreement in science and technology, celebrated between Brazil (Ministry for the Environment) and Germany (Zentrum für Marine Tropenökologie) and its objective was to learn about the role of mangrove forests in coastal water diversity and productivity in northeastern Brazil.

Brazil's marine and coastal environments have been suffering a considerable degradation process in recent years generated by the growing pressure on marine and continental natural resources and the limited capacity of these ecosystems to absorb these impacts. The growth in population and its development are the main causes for environmental changes, and these impacts are associated to the introduction of nutrients, changes or destruction of habitats, changes in sedimentation, exploration of fishing resources and industrial pollution (Santos and Câmara, 2002).

Primary phytoplanktonic production in the open sea is basically controlled by the availability of nutrients and light. The small concentrations of nutri- ent salts lead to a low productivity of the waters of Northeast Brazil influenced also by low water discharge on the coastline (Medeiros et al., 1999). The availability of nutrients, in turn, is a function of physical factors, such as turbulent diffusion, advective processes, phytoplanktonic sedimentation and complex chemical mineralization processes (Macêdo et al., 2004).

Studies on phytoplankton on the continental shelf and ocean area of Pernambuco are relatively scarce, being limited to the neritic region approximately 15 miles off the coast (Eskinazi-Leça et al., 2004) and previous investigations have been restricted to some papers about hydrology and phytoplankton density and biomass (Medeiros et al., 1999).

The objective of this study was to determine the biodiversity of the microphytoplankton community associated with the hydrological features and characterise the community's structure through specific diversity rates, evenness and multivariate analysis.

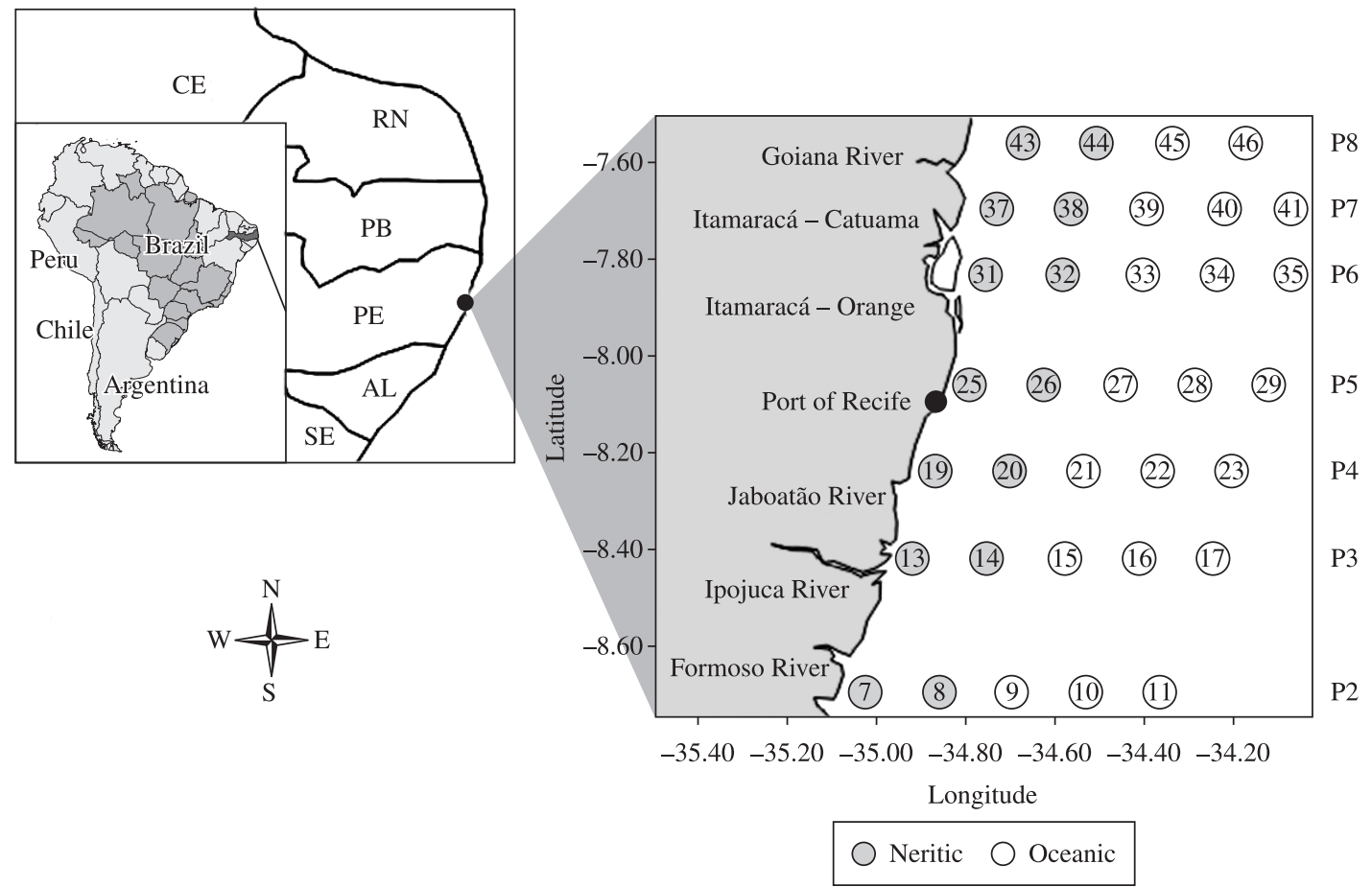

Figure 1. Sampling stations in neritic and oceanic waters of the State of Pernambuco. 


\section{Material and Methods}

The samples were collected from February 25 to March 3, 1995, on board the R.V "Victor Hensen". A total of 34 stations along seven profiles perpendicular to the coast were sampled during the cruise being 14 neritic and 20 oceanic (Figure 1). The studied profiles were positioned in front of the main estuaries in the state of Pernambuco-Brazil: Profile 2-Formoso River; Profile 3-Ipojuca River; Profile 4-Jaboatão River; Profile 5-Port of Recife; Profile 6-Itamaracá-Orange; Profile 7Itamaracá-Catuama and Profile 8-Goiana River. The hydrological data were collected at three depths (surface, mid depth and near the bottom) for stations shallower than $100 \mathrm{~m}$ and at surface, 50, 100, 150, and $200 \mathrm{~m}$ depth for the remaining stations, using a rosette with Niskin type $5 \mathrm{~L}$ capacity oceanographic bottles and analysed according to the following methods: temperature and salinity (CTD profiler with the SEASOFT computer program); dissolved oxygen, (Strickland and Parsons, 1972) and nutrients (Grasshoff et al., 1983).

For the phytoplankton study the samples were collected using a Baby Bongo net with a $64 \mu \mathrm{m}$ mesh size. Oblique trawls were made at depths from $14 \mathrm{~m}$ at neritic stations and $150 \mathrm{~m}$ at oceanic ones. The samples were preserved in $4 \%$ buffered formaldehyde. Identification of the species was performed according to Desikachary, (1959), Anagnostidis and Komárek (1988), Round et al. (1992), Licea et al. (1995) and Tomas (1997). The relative abundance of the species was calculated in percentages, and the following categories were used: Dominant $\geq 50 \%$; Abundant $\leq 50 \%->30 \%$; Little Abundant $\leq 30 \%$ $->10 \%$ and Rare $\leq 10 \%$. For frequency of occurrence, the species were classified in the following categories: Very Frequent $\geq 70 \%$; Frequent $\leq 70 \%->30 \%$; Little Frequent $\leq 30 \%->10 \%$ and Sporadic $\leq 10 \%$. Species diversity was based on Shannon (1948) and the evenness on Pielou (1977). Multivariate analysis was carried out taking into account the association of the species using taxa with frequencies of occurrence greater than $30 \%$ and the Bray and Curtis coefficient. Analysis of the main components was based on species and hydrological parameters applying the Pearson moment-product correlation coefficient. NTSYSpc 2.1 (Numerical Taxonomy and Multivariate Analysis System) by Metagraphics Software Corporation, California - USA was used.

\section{Results}

\subsection{Hydrology}

Superficial water temperature oscillated between 28.5 and $29.1{ }^{\circ} \mathrm{C}$, with the slightly higher values found near the coast, and decreasing towards the oceanic region. The vertical temperature distribution, only considered at the oceanic stations at depths of $(0,50,100$ and $150 \mathrm{~m})$ presented values ranging between 18.3 and $29{ }^{\circ} \mathrm{C}$, with the tendency to drop from the superficial layer to the deeper ones (Figure 2a).
Surface salinity presented a slight increase at the stations closer to the coast. In relation to vertical distribution, elevated values were observed on the surface and a maximum between 50 and $100 \mathrm{~m}$, with a gradual reduction in the deeper layers. Salinity values oscillated between 35.84 PSU at 150 meters and 37.16 PSU at $100 \mathrm{~m}$ (Figure 2b)

The elaboration of the T-S diagram permitted the characterisation of water masses present on the shelf and oceanic area in hot and saline superficial waters, with a predominance of Tropical Surface Water (TSW), salinities greater than 36.00 PSU and temperatures higher than $18^{\circ} \mathrm{C}$. This water mass was observed throughout the water column encompassing depths of 0 to $150 \mathrm{~m}$. South Atlantic Central Water (SACW) occupied the greatest depths with salinity values of 34.50 PSU and 36.00 PSU and temperatures ranging from 8 to $18{ }^{\circ} \mathrm{C}$, at depths of more than $150 \mathrm{~m}$ (Figure 2c).

Concentrations of dissolved oxygen in the superficial layer did not show a regular distribution pattern with values near saturation and in some cases even higher, throughout the studied area. In relation to the vertical distribution of dissolved oxygen, higher values were observed in areas near the surface. The minimum and maximum values recorded were $4.42 \mathrm{~mL} . \mathrm{L}^{-1}$ at $150 \mathrm{~m}$ with saturation rates of $85.99 \%$, and $4.88 \mathrm{~mL} \cdot \mathrm{L}^{-1}$ at $50 \mathrm{~m}$ with $108.44 \%$ saturation (Figure 2 d).

Spatial distribution of nitrite-N on the superficial layer presented similar values in all profiles and where the highest values occurred most often at the neritic stations. In relation to vertical distribution, nitrite- $\mathrm{N}$ concentrations did not present a regular distribution pattern, but a slight increase in the concentrations was observed at most depths. The minimum and maximum values ranged between $0.02 \mu \mathrm{M}$ in most superficial layers and $0.08 \mu \mathrm{M}$ at a depth of $150 \mathrm{~m}$ (Figure 2e). Nitrate-N presented slight variations at the superficial level, and a slight increase in concentration was observed at stations furthest from the coast. In relation to vertical distribution, the values were highest at the greatest depths, ranging between 0.02 and $8.47 \mu \mathrm{M}$ (Figure 2f). Variations in silicate-Si concentrations in the superficial layer were similar to the rest of the nutrients. In the vertical distributions, these concentrations tended to increase with depths, most often presenting the highest values at depths between 150 and $200 \mathrm{~m}$. The minimum recorded value for silicate was $0.95 \mu \mathrm{M}$ and the maximum was $8.02 \mu \mathrm{M}$ (Figure $2 \mathrm{~g}$ ). With regard to phosphate-P distribution in the superficial layer, the highest values were recorded at the neritic stations. In the vertical distributions, these concentrations tended to increase with depths, presenting the highest values at depths of 150 and $200 \mathrm{~m}$ (Figure 2h). The recorded values ranged between a minimum of $0.02 \mu \mathrm{M}$ and a maximum of $1.16 \mu \mathrm{M}$.

\subsection{Microphytoplankton composition}

A total of 173 infrageneric taxa were identified, distributed among the following divisions: Dinophyta (103 taxa), 


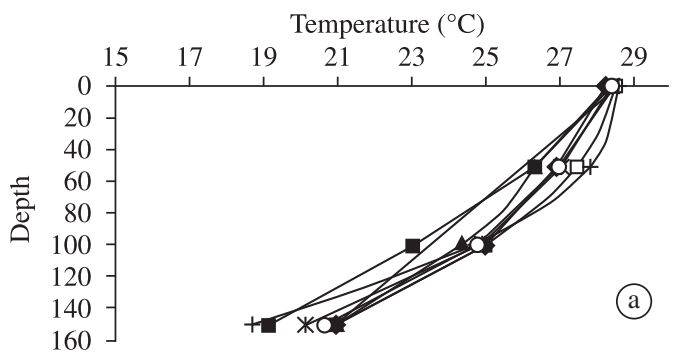

Salinity (psu)
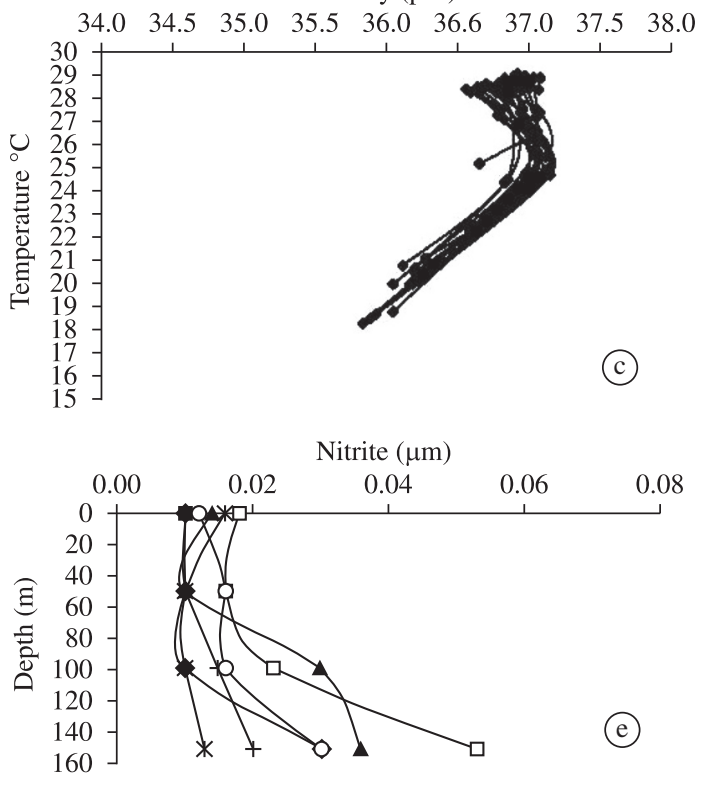

Silicate $(\mu \mathrm{m})$

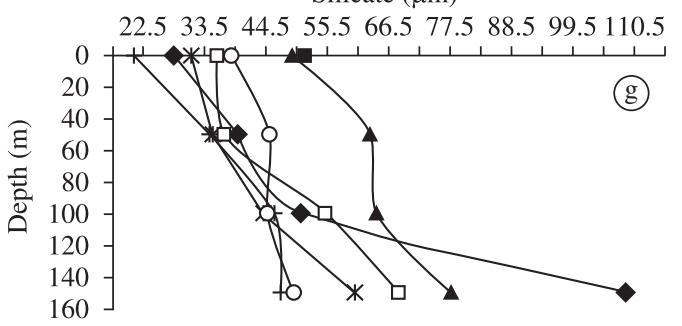

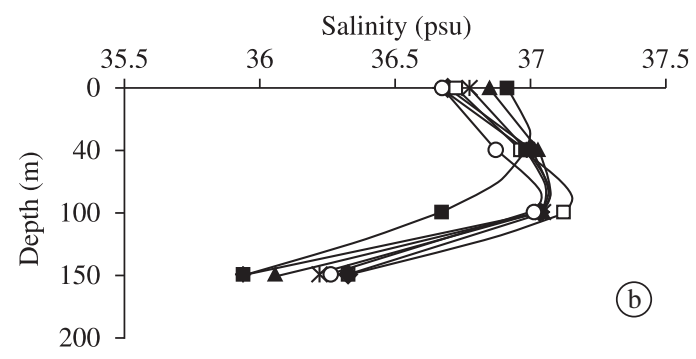

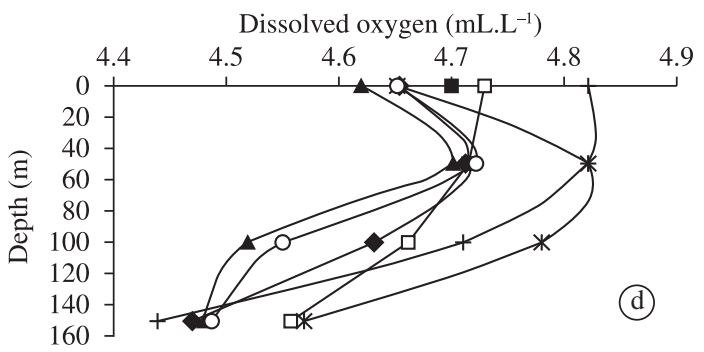

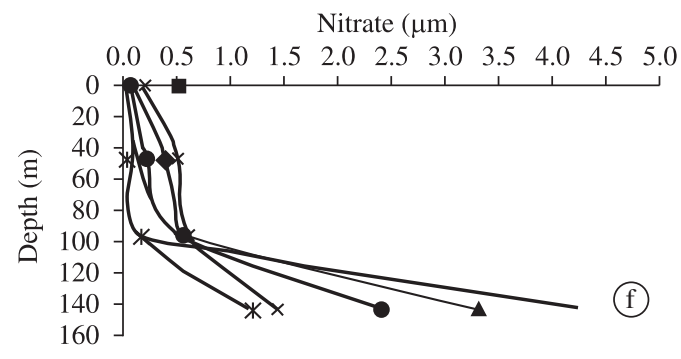

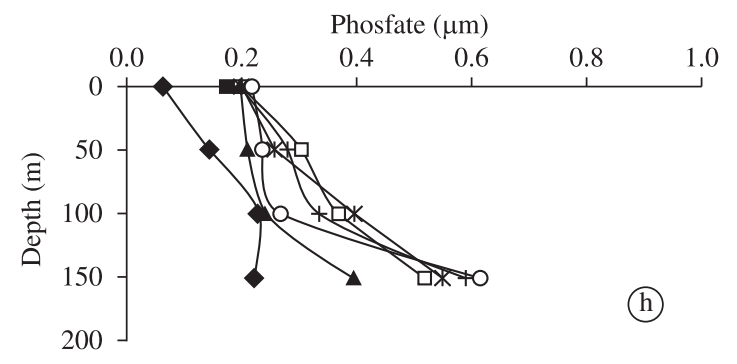

Profile 2

Profile 3

Profile $4 \quad \square-$ Profile 5

* Profile $6 \multimap$ - Profile $7 \multimap$ Profile 8

Figure 2. Vertical distribution of a) Temperature; b) Salinity; c) T-S diagram; d) Dissolved Oxygen; e) Nitrite; f) Nitrate; g) Silicate; and h) Phosfate for the different profiles in the state of Pernambuco.

Bacillariophyta (61 taxa), Cyanobacteria (7 taxa), Chlorophyta and Chrysophyta (1 taxon).

The group of dinoflagellates was the most representative and the Ceratiaceae family stood out with 47 taxa. The diatoms, the second largest contributor, were represented by the Rhizosoleniaceae (seven species) and Coscinodiscaceae (six species) families. The cyanophytes, chlorophytes and silicoflagellates contributed little to the floristic composition.
Few species were dominant in the area, the diatom Leptocylindrus danicus Cleve and the cyanobacteria Trichodesmium erythraeum Ehrenberg stood out for being at most stations. The abundant species were represented by Trichodesmium erythraeum at most stations, Oscillatoria princeps Vaucher ex Gomont and Leptocylindrus danicus. The little abundant and rare species predominated during the studied period at most stations.

The very frequent species were represented by the dinoflagellates: Ceratocorys horrida Stein, Pyrocystis 

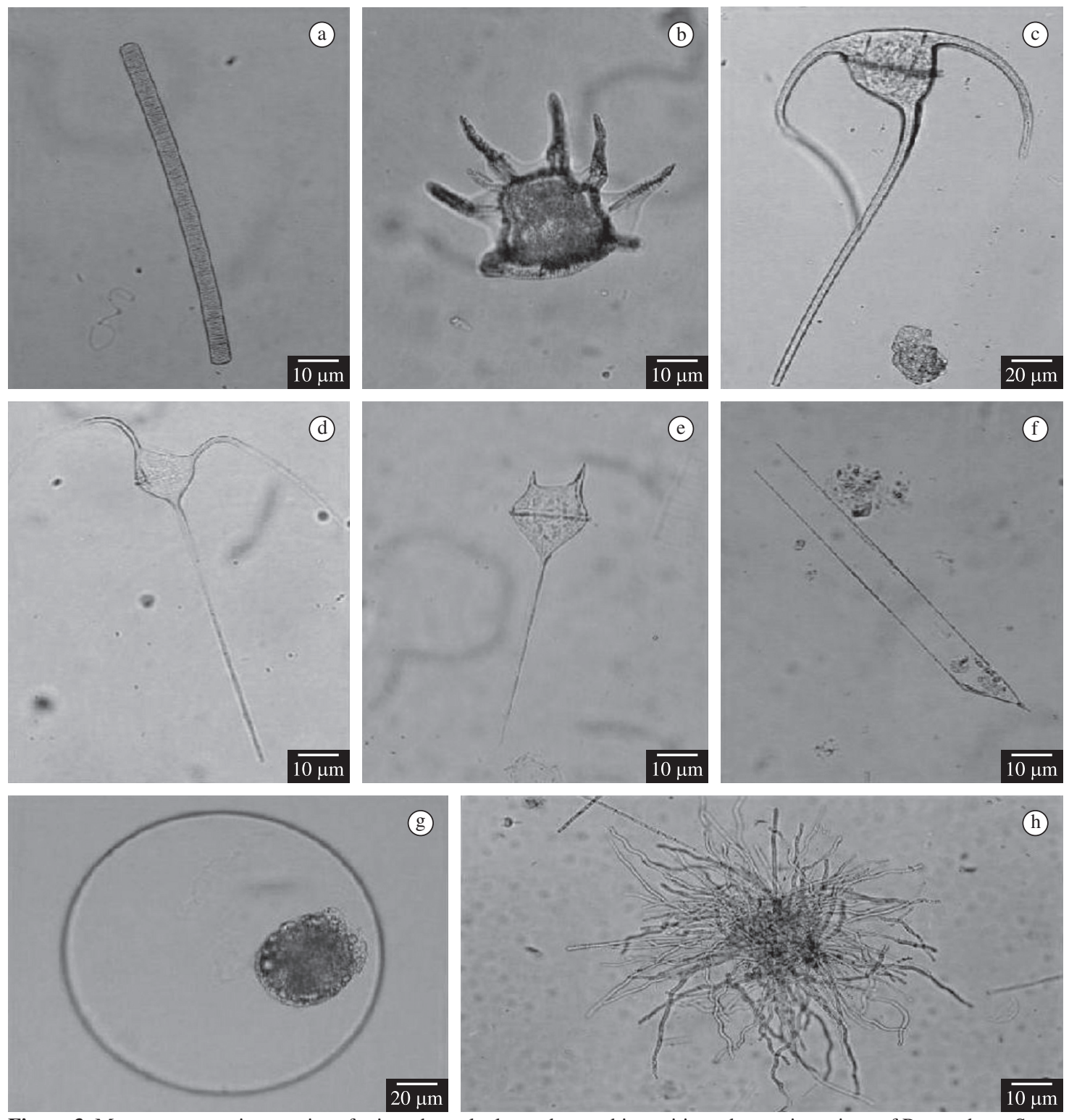

Figure 3. Most representative species of microphytoplankton observed in neritic and oceanic regions of Pernambuco State: a) Oscillatoria princeps Vaucher ex Gomont; b) Ceratocorys horrida Stein; c) Ceratium contortum var. contortum Gourret (Cleve); d) Ceratium macroceros var. gallicum (Kofoid) Sournia; e) Ceratium pentagonum var. tenerum Jörgensen; f) Rhizosolenia styliformis Brightwell; g) Pyrocystis noctiluca Murray ex Haeckel; and h) Trichodesmium erythraeum Ehrenberg.

noctiluca Murray ex Haeckel, Ceratium contortum var. contortum Gourret (Cleve), Ceratium pentagonum var. tenerum Jörgensen, Ceratium teres Kofoid and Ceratium macroceros var. gallicum (Kofoid) Sournia; the cyanobacteria Trichodesmium erythraeum and Oscillatoriaspp (100\% of the samples), Oscillatoria princeps and the diatom Rhizosolenia styliformis Brightwell (Figure 3).

Specific diversity varied between very low and high, presenting values ranging between 0.71 bits.cell $^{-1}$ and 3.46 bits.cell $^{-1}$ with very low values at the neritic stations, mainly related to the Trichodesmium erythraeum species. Values referring to evenness varied from 0.14 to 0.65 , without any significant values or an equitable distribution being found (Figure 4).

Among the infrageneric taxa identified, outranked the oceanic marine plankton species $(58.39 \%)$, followed by neritic/oceanic marine plankton $(16.78 \%)$, neritic marine plankton $(11.67 \%)$, tycoplankton $(10.94 \%)$ and freshwater $(2.18 \%)$.

\subsection{Multivariate analysis}

\subsubsection{Association of species}

The data analysis revealed two main groups. The first subdivided into 2 subgroups. The first subgroup 
was the largest, associating 37 species characteristic of the oceanic and neritic/oceanic regions, represented by Amphisolenia bidentata Schröder, Ceratium massiliense var. massiliense (Gourret) Karsten, Ceratium macroceros var. gallicum, Ornithocercus magnificus Stein, Pyrocystis robusta Kofoid, Ceratium euarcuatum Jörgensen, Pyrocystis noctiluca, Ceratium pentagonum var. tenerum, Ceratium contortum var. contortum, Ceratocorys horrida, Ceratium teres, Rhizosolenia styliformis, Ceratium tripos var. tripos Balech, Oscillatoria sp, Hemiaulus membranaceus Cleve, Ceratium candelabrum var. candelabrum (Ehrenberg) Stein, Ornithocercus splendidus Schütt, Ceratium contortum var. karstenii Pavillard, Goniodoma polyedricum (Pouchet) Jörgensen, Ceratocorys armata (Schütt) Kofoid, Ceratium carriense Gourret, Ornithocercus steinii Schütt, Ceratium contrarium Gourret, Ceratium vultur $f$. summatranum (Karsten) Sournia, Chaetoceros coarctatus Lauder, Cladopyxis brachiolata Stein, Protoperidinium elegans (Cleve) Balech, Phalacroma cuneus (Schütt) Abé, Pyrocystis fusiformis Wyville-Thomson ex Murray, Ceratium tenue var. tenuissimum (Kofoid) Graham et Bronikowsky, Ceratium tripos VAR. tripodioides Jörgensen (Paulsen), Ceratium tripos var. atlanticus (Ostenfeld) Paulsen, Ceratium trichoceros (Ehrenberg) , Rhizosolenia bergonii Péragallo, Ceratium vultur var. recurvum (Jörgensen) Schiller. The second subgroup was comprised of 4 typically oceanic species, indicative of oligotrophic conditions and being frequent in the area: Ceratium cephalotum (Lemmerman) Jörgensen, Ceratium gibberum var. dispar (Pouchet) Sournia, Rhizosolenia castracanei Péragallo and Planktoniella sol (Wallich) Schütt.

The second group associated 6 species that characterised the area in terms of dominance and frequency of occurrence, and were considered the key species in the area:
Climacodium frauenfeldianum Grunow, Trichodesmium erythraeum, Oscillatoria spp., Istmia enervis Ehrenberg, Oscillatoria princeps and Melchersiella hexagonalis C. Teixeira (Figure 5).

\subsubsection{Principal component analysis}

The first three principal components explained $50.91 \%$ of data variance. The representation on the bidimensional plane of factors 1 and 2 explained 37.72 of data variance and revealed two main groups: On the right side of the projection, the group of typically oceanic species: Ceratium teres, Ceratium contortum var. contortum, Ceratium macroceros var. gallicum, Ceratocorys horrida, Ceratium pentagonum var. tenerum and Pyrocystis noctiluca, characterised by the area's oligotrophy, and on the left side, the neritic influence can be observed, where nutrients and Trichodesmium erythraeum, Oscillatoria spp. and Oscillatoria princeps play a relevant role in community structuring (Figure 6).

\section{Discussion}

Costa et al. (1989) observed small variations in temperature throughout the year on the continental shelf in northeastern Brazil and the existence of reduction from the coastal region to the oceanic. They also reported a homogenous distribution in the superficial layer, followed by an accentuated permanent thermocline that increases with the depth. In the northern region the thermocline was shallower ( $80 \mathrm{~m}$ on average) and had stepwise shape while along the central and southern section it was deeper (98 to $140 \mathrm{~m}$ ) and smoother (Medeiros et al., 1999). This parameter forms an ecological barrier and consequently impedes the renewal of nutrients between the superficial and the deeper layers.

The data obtained in this study corroborate the observations found by the authors where the temperature in

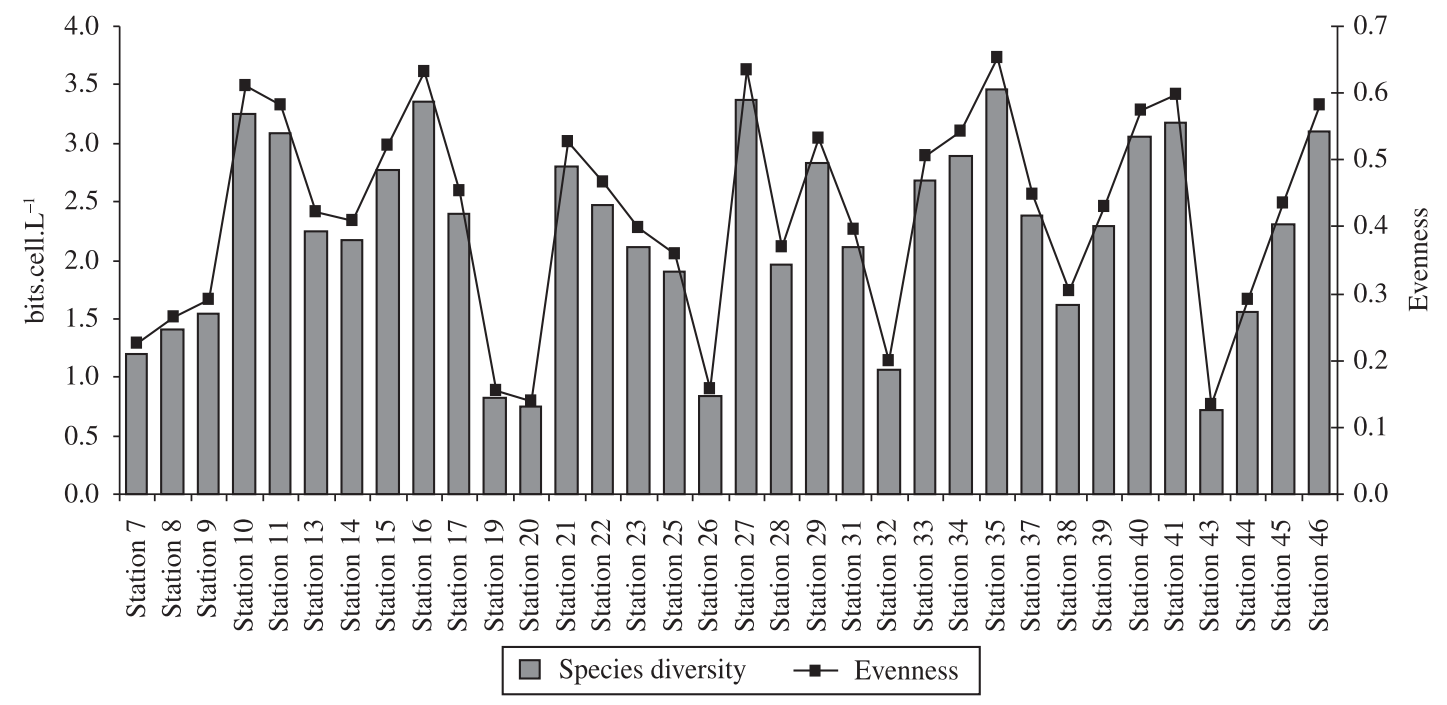

Figure 4. Species diversity (bits.cells ${ }^{-1}$ ) and evennness for each collected station in Pernambuco state. 
the neritic and oceanic area of the State of Pernambuco varied little at the superficial stations, with maximum temperatures between 20 and $60 \mathrm{~m}$, and an abrupt reduction after that depth, delimiting the beginning of the thermocline.

Salinity variations are less evident in continental shelf than in the estuary and coastal areas since the influence of the rivers is small in this region. Medeiros et al. (1999) reported that salinity in the northeastern Brazil continental shelf and oceanic region varied between 36.2 PSU and 37.8 PSU at the surface, showing a gradiente with hypersaline conditions near the coast, and also pointed out that immediately below the thermocline, salinity distribution showed a pattern very similar to that of temperature. The high salinity values on the surface of neritic and oceanic waters in the State of Pernambuco could be justified by the fact that the region is located between the tropics, where there is a predominance of trade winds and in some areas the evaporation rate exceeds precipitation (Macedo et al., 2004).

Throughout this study, the superficial salinity values were high. However, the maximums were recorded at depths of 50 to $100 \mathrm{~m}$, clearly indicating the influence of intense evaporation processes. Factors such as salin-

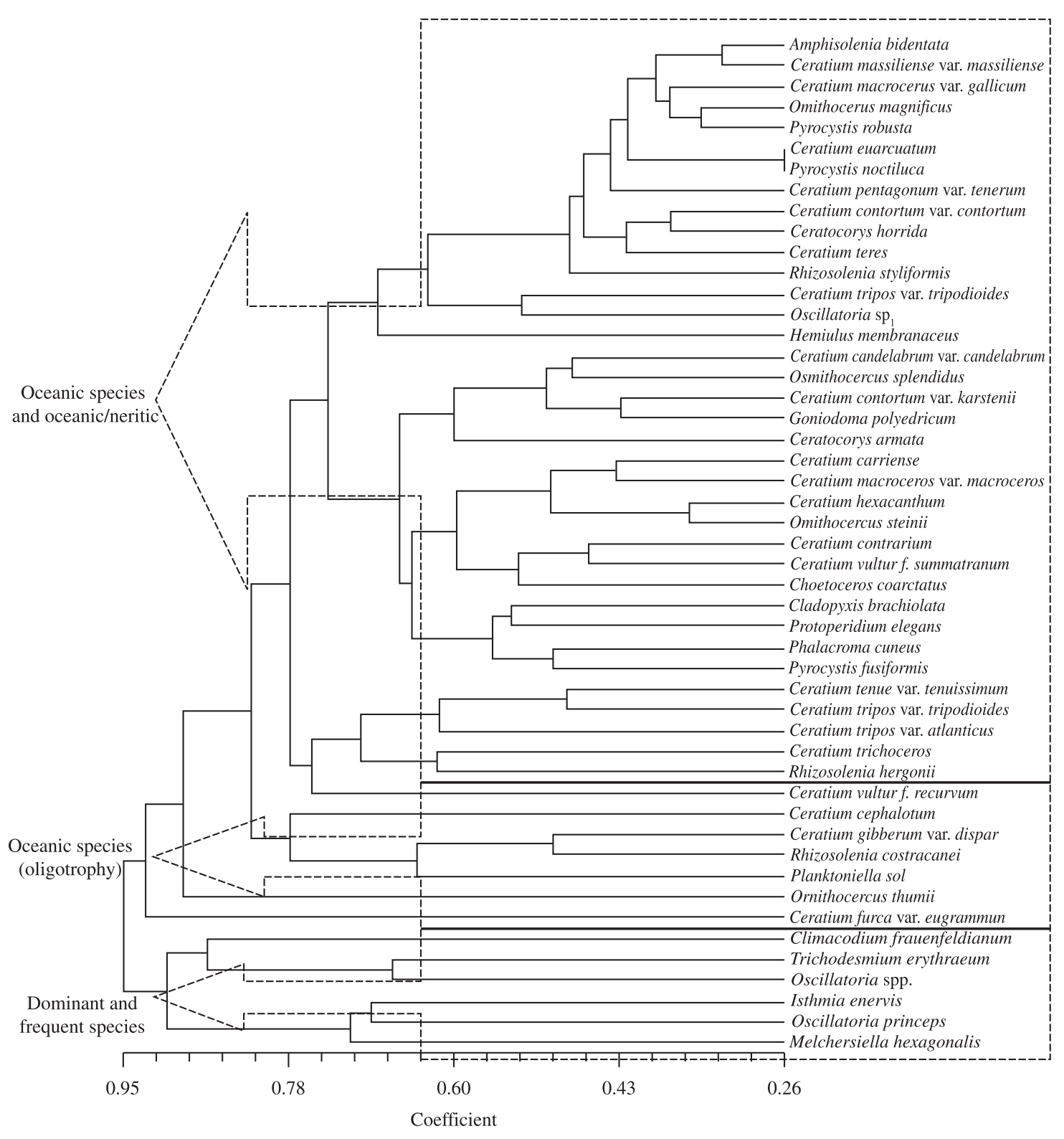

Figure 5. Dendrogram showing species similarity of the most significant microphytoplankton species in neritic and oceanic waters of the state of Pernambuco. 
ity and temperature can influence the distribution of the species; however, in this study, the principal components analysis (PCA) showed that they were not the determining factors in the distribution of phytoplankton community in the profiles studied.

Costa et al. (1989) observed that the Pernambuco continental shelf waters were normally supersaturated with dissolved oxygen, characterising an area with mixtures caused by waves and currents. Medeiros et al. (1999) observed that the concentration of dissolved oxygen was greater at the Superficial and subsuperficial layers and reduced gradually with depth.

In this study, the concentrations of dissolved oxygen in the superficial layers were high at all stations, with percentages near or greater than saturation. A stability of these concentrations was also observed until approximately $50 \mathrm{~m}$ and then gradually decreasing with depth. The principal component analysis demonstrated a positive correlation between the most representative species and dissolved oxygen. The values for dissolved nutrients on the Pernambuco continental shelf showed characteristics of oligotrophic regions. The distribution of these elements in the studied region revealed two defined patterns: one, superficial with small variations and the other, vertical, with more accentuated variations starting at the base of the photic layer, forming the nutricline, with an inverse relationship to the thermocline, registering a minimum at the superficial layer and a maximum at a depth of $150 \mathrm{~m}$. The data obtained are according to Medeiros et al. (1999) where the concentrations of nutrients were lower at the surface and showed a maximum just below the thermocline.

The microphytoplankton community in the oceanic and continental shelf region of Pernambuco proved to be much diversified with some of the species playing an important role due to their dominant and very frequent presence throughout the entire study period. The dinoflagellates stood out as the main representative of local microphytoplankton in terms of biodiversity and frequency of occurrence, especially at the stations furthest away from the coast. According to Lalli and Parson (1993) the dominance of this group is associated with the fact they are best adapt to regions with low concentrations of nutrients, especially in tropical and subtropical

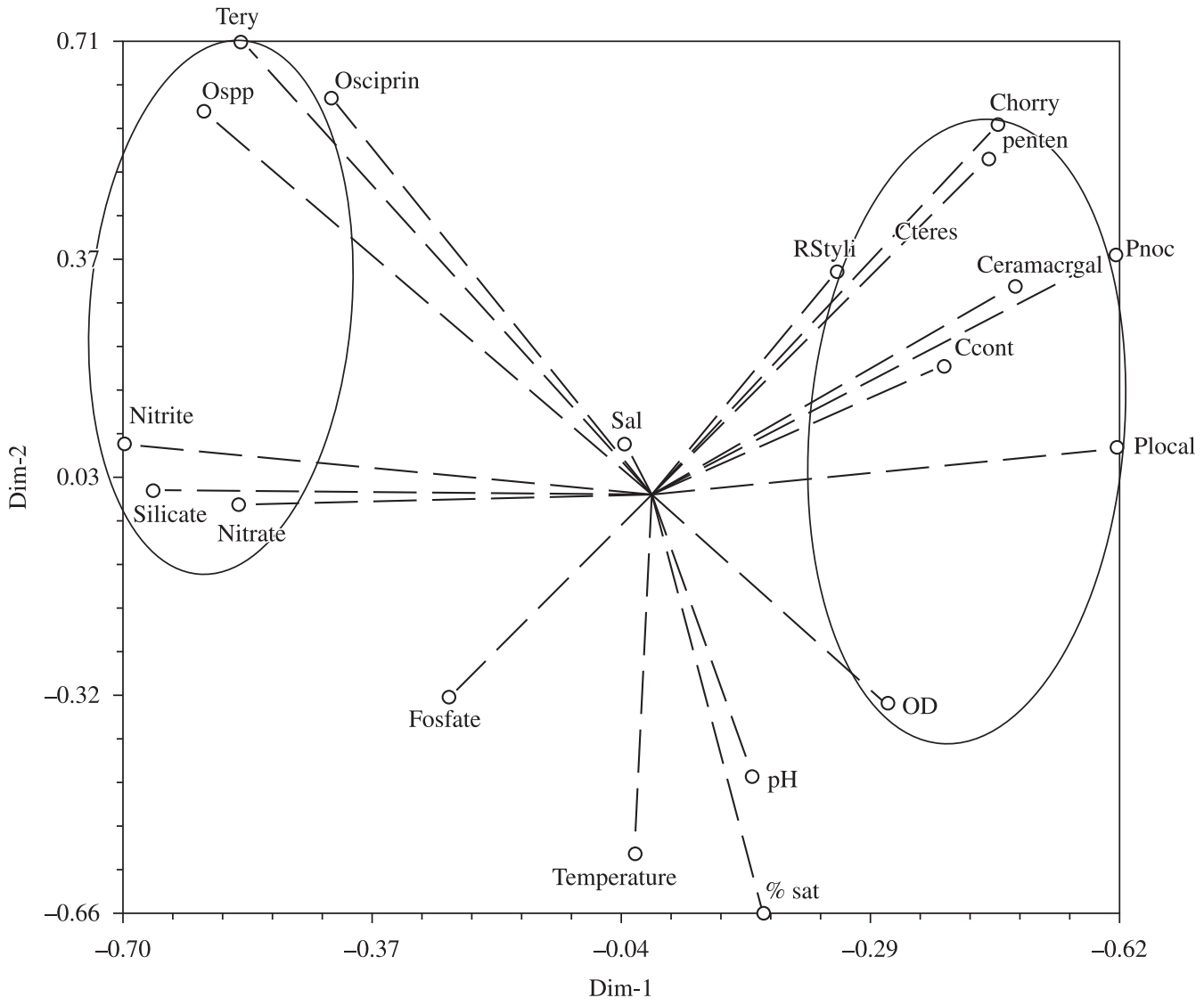

Figure 6. PCA showing the contribution of taxa and environmental parameters in the state of Pernambuco (Tery = Trichodesmium erythraeum; Osciprin = Oscillatoria princeps; Ospp = Oscilatoria spp; Chorry = Ceratocorys horrida; Cpenten $=$ Ceratium pentagonum var. tenerum; Cteres $=$ Ceratium teres $;$ Rstyli $=$ Rhizosolenia styliformis $;$ Pnoc $=$ Pyrocystis noctiluca $;$ Ceramacrogal $=$ Ceratium macroceros var. gallicum $;$ Ccont $=$ Ceratium contortum var. contortum . 
waters. Among the dinoflagellates, the Ceratium genre is referred to as the most important component of marine phytoplankton in the North Atlantic (Raine et al., 2002) and according to Dodge and Marshall (1994) there is a direct relationship between the increase in water temperatures and the number of species. Therefore, this corroborates with one of the basic dogmas of biogeography where the number of species is high in low latitudes, also underscoring that this genre can be used as a bioindicator for water masses and global temperature changes.

In this study, the Ceratium genre was the most prominent with 27 species, 18 varieties and 2 forms. Its marked presence in all profiles and at all stations, with predominance in the stations furthest from the coast, makes this an important genre in the area not only because of its distribution, but also in terms of species richness and frequency of occurrence. Among the identified species and varieties C. contortum var. contortum, C. macroceros var. gallicum, C. pentagonum var. tenerum and C. teres stood out as most representative, being frequently registered as indicators of the Brazil Current (Balech, 1988). Passavante (1979) identified 43 species, 16 of which were cited for the first time for Brazil, concluding that the Ceratium contortum var. contortum species had a broader distribution in the Pernambuco Continental Shelf.

In the same area, Koening and Lira (2005) identified 58 infrageneric taxa, highlighting the $C$. contortum var. kastenii, C. macroceros var. macroceros, C. teres, C. euarcuatum and $C$. tripos tripos species as being the most representative, and Koening and Macedo (1999), in a profile located along the north coast of Pernambuco (Itamaracá) identified 45 species and 4 varieties where the most representative species were: Ceratium macroceros, C. massiliense, C. pentagonum, C. tripos var. pulchellum and $C$. vultur var. vultur. Besides the Ceratium species, other species, such as Pyrocystis noctiluca and Ceratocory horrida were also the most widely distributed in the area.

The diatoms were the second most representative group and different from the dinoflagellates, they are more important in tropical coastal and estuarine regions, where they can comprise up to $80 \%$ of the network's phytoplankton (Eskinazi-Leça et al., 2004). Fernandes and Brandini (2004) also observed that the diatoms were the second contribution group in subtropical waters of southern Brazil's oceanic and continental shelf areas.

The dominance of diatoms increased in those stations located at the edge of the continental shelf, especially the Rhizosoleniaceae family comprised only of the Rhizosolenia genre, with 7 species. Rhizosolenia styliformis was the species considered to be very frequent in microphytoplankton. This fact can be explained because it is a marine plankton species found in neritic as well as oceanic waters and well represented in the Pernambuco continental shelf (Koening and Macedo, 1999).
The Leptocylindrus danicus species was dominant in the area, reaching $85 \%$ in relative abundance. Moreira Filho et al. (1999) recorded this species as neritic in marine and estuarine waters in the states of Espírito Santo, Bahia, Sergipe and Alagoas. Fernandes and Brandini (2004) also registered this species for the Paraná continental shelf in eutrophic conditions.

The cyanobacteria were little represented in the local flora, however, Trichodesmium erythraeum was the species that predominated in all profiles, especially at the neritic stations, in terms of frequency of occurrence as well as relative abundance. Capone et al. (1997) highlighted the Trichodesmium genre as cosmopolitan cyanobacteria with broad distribution in oligotrophic and high stability regions, being recorded in the tropical and subtropical Atlantic, Pacific and Indian oceans, as well as the Caribbean and South China Seas. The abundance of the Trichodesmium genre has been observed by several authors in the southern region, influenced by the Brazil Current.

Koening and Macedo (1999), studying the northern coast of Pernambuco, observed that the Trichodesmium erythraeum species predominated at all stations, reaching abundance percentages at some stations greater than $70 \%$. Queiroz et al. (2004) reported the occurrence of Trichodesmium genre blooming between September and December along the coast and specifically the Paraná continental shelf.

The phytoplankton community showed greater taxonomic richness of organisms at the oceanic stations where it was more evident at the edge of the continental shelf. Medeiros et al. (1999) affirmed that these physiographic features can be factors that contribute to the increase in nutrients at stations located closest to the edge of the continental shelf, showing that this structure has been another important factor contributing to the productivity of oceanic waters in northeastern and southern Brazil.

From an ecological point of view, the phytoplankton community was characterised by oceanic and neritic/ oceanic marine plankton species, mainly represented by dinoflagellates.

The values for specific diversity in the studied area varied spatially at the stations. Low diversity was observed in the neritic areas and greater diversity in the oceanic areas, as a result of the latter's stability. Trichodesmium erythraeum was considered opportunist (r- strategist), being responsible for the low rates of specific diversity at the stations located on the continental shelf.

Principal component analysis (PCA) showed there was a direct correlation of these species with the principal inorganic nutrients. According to Paerl (1988), the cyanobacteria are extremely opportunistic algae and depend on the environment's stability to reproduce by virtue of their peculiar ecological and physiological characteristics. On the other hand, high specific diversity was ascertained at the oceanic stations due to the greater diversity of dinoflagellates, non-specialist spe- 
cies (k-strategists), and common in the area and with equitable distribution.

It can be concluded that the study area is characterised by oligotrophic conditions, corroborated by low concentrations of nutrients, indicating that the phytoplankton community is associated with local hydrological conditions and species requirements.

Acknowledgements - We are grateful to $\mathrm{CNPq}$ for financial support, and to the Brazilian and German Ministries of Science and Technology.

\section{References}

ANAGNOSTIDIS, K. and KOMÁREK, J. 1988. Modern approach to the classification system of cyanophytes. Archive Hydrobiology, vol. 50, p. 327-472. (Oscillatoriales).

BALECH, E. 1988. Los dinoflagelados del Atlantico Sudoccidental. Madrid: Publicaciones Especiales/Instituto Espanol de Oceanografi. 310 p.

CAPONE, DG., ZEHR, JP., PAERL HW., BERGMAN, B. and CARPENTER, EJ. 1997. Trichodesmium, a globally signifícant marine cyanobacterium. Science, vol. 276, no. 5316, p. $1221-1229$.

COSTA, KM., QUEIROZ, CM. and MACEDO, SJ. 1989. Hidrologia e plâncton da plataforma continental de Pernambuco. In Anais do 3 Encontro Brasileiro de Gerenciamento Costeiro. p. 337-362. (v. 1, Variação das características físico-químicas da água).

DESIKACHARY, TV. 1959. Cyanophyta. New Delhi: Indian Council of Agricultural Research. 686 p.

DODGE, JD. and MARSHALL, HG. 1994. Biogeographic analysis of the armored planktonic dinoflagellate Ceratium in the north Atlantic and adjacents seas. Journal Phycology, vol. 30, no. 6, p. $905-922$

ESKINAZI-LEÇA, E., KOENING, ML. and SILVACUNHA, MGG. 2004. Estrutura e dinâmica da comunidade fitoplanctônica. In ESKINAZI-LEÇA, E., NEUMANNLEITÃO, S. and COSTA, MF. (Ed.). Oceanografia: um cenário tropical. Recife: Bagaço. p. 353-373.

FERNANDES, LF and BRANDINI, FP. 2004. Diatom associations in shelf waters off Parana State, Southern Brazil: annual variation in relation to environmental factors. Brazilian Journal of Oceanography, vol. 52, no. 1, p. 19-34.

GRASSHOFF, K., EHRARDT, M. and KREMELING, K. 1983. Methods of sea water analysis. New York: Verlag Chemie. $317 \mathrm{p}$.

KOENING, ML. and MACEDO, SJ. 1999. Hydrology and phytoplankton community structure at Itamaracá-Pernambuco (Northeast Brazil). Brazilian Archives of Biology and Technology, vol. 42, no. 2, p. 381-392.

KOENING, ML. and LIRA CG. 2005. O gênero Ceratium Schrank (Dinophyta) na plataforma continental e águas oceânicas do estado de Pernambuco, Brasil. Acta Botanica Brasilica, vol. 19, no. 2, p. 391-397.
LALLI, CM. and PARSONS, TR. 1993. Biological Oceanography: an introduction. Oxford: Butterworth Heinemann. 301 p.

LICEA, L., MORENO, JL., SANTOYO, H. and FIGUEROA, G. 1995. Dinoflagelados del Golfo de Califórnia. Califórnia: Universidad Autónoma de Baja Califórnia Sur. 165 p.

MACÊDO, SJ., MUNIZ, K. and FLORES-MONTES, MJ. 2004. Hidrologia da região costeira e plataforma continental do estado de Pernambuco. In ESKINAZI-LEÇA, E., NEUMANNLEITÃO, S. and COSTA, MF. (Ed.). Oceanografia: um cenário tropical. Recife: Bagaço. p. 255-286.

MEDEIROS, C., MACEDO, SJ., FEITOSA, FAN. and KOENING, ML. 1999. Hydrography and phytoplankton biomass and abundance of North-East Brazilian waters. Archive of Fishery and Marine Research, vol. 47, no. 2/3, p. 133-151.

MOREIRA-FILHO, H., ESKINAZI-LEÇA, E., VALENTEMOREIRA, IM. and CUNHA, JA. 1999. Avaliação taxonômica e ecológica das Diatomáceas (Chrysophyta Bacillariophyceae) marinha e estuarinas nos Estados do Pernambuco, Paraíba, Rio Grande do Norte, Ceará, Piauí, Maranhão, Pará e Amapá, Brasil. Trabalhos Oceanográficos da Universidade Federal de Pernambuco, vol. 27, no. 2/3, p. 55-90.

PAERL, HW. 1988. Growth and reproductive strategies of freshwater blue-green algae (cyanobacteria). In SANDGREN, CD. (Ed.). Growth and reproductive strategies of freshwater phytoplankton. Cambridge: Press Syndicate of the University of Cambridge. p. 261-315.

PASSAVANTE, JZO. 1979. Contribuição ao estudo dos dinoflagelados da Plataforma Continental de Pernambuco/ Brasil. Trabalhos Oceanográficos da Universidade Federal de Pernambuco, vol. 14, p. 31-54.

PIELOU, EC. 1977. Mathematical ecology. New York: John Wiley \& Sons. 385 p.

QUEIROZ, RL., BRANDINI, FP. and PELLIZARI, FM. 2004. Dynamics of microalgal communities in the water column/ sediment interface of the inner shelf off Paraná state, southern Brazil. Brazilian Journal of Oceanography, vol. 52, no. 3/4, p. 183-194.

RAINE, R., WHITE, M. and DODGE, JD. 2002. The summer distribution of net plankton dinoflagellates and their relation to water movements in the NE Atlantic Ocean, West of Ireland. Journal of Plankton Research, vol. 24, no. 2, p. 1131-1147.

ROUND, FE., CRAWFORD, RM. and MANN, DG. 1992. The Diatoms biology and morphology of the genera. Cambridge: University Press. 747 p.

SANTOS, TCC. and CÂMARA, JBD. 2002. Geo Brasil: perspectivas do meio ambiente no Brasil. Brasília: IBAMA. $440 \mathrm{p}$.

SHANNON, CE. 1948. A mathematical theory of communication. Bulletin of System Technology Journal, vol. 27, p. $379-423$.

STRICKLAND, JDH. and PARSONS, TR. 1972. A practical handbook of seawater analysis. Bulletin Fisheries Research board of Canada, vol. 167, p. 1-205.

TOMAS, CR. 1997. Identifying marine diatoms and dinoflagellates. San Diego: Academic Press. 598 p. 